\title{
THE CRIMINALIZATION AND PROSECUTION OF SEXUAL VIOLENCE OFFENCES AT NATIONAL LEVEL: THE NEED FOR LEGISLATIVE REFORM IN SOUTH SUDAN
}

\author{
David Abrahams* \\ BJuris LLB LLM LLM \\ Lecturer in the Faculty of Law \\ Nelson Mandela Metropolitan University \\ Port Elizabeth, South Africa
}

\section{SUMMARY}

Sexual violence against women in South Sudan is rife amidst the ongoing internal armed conflict that erupted on 15 December 2013. As a new country emerging from civil wars spanning more than two decades, South Sudan has an enormous, yet unenviable task of reconstruction and development in all spheres. The justice system is no exception, and to this end it needs serious reform of its customary and statutory laws in order to ensure that it can effectively criminalize these crimes and prosecute offenders of sexual violence. This article reflects on whether South Sudan currently has the capacity to achieve this.

\section{$1 \quad$ INTRODUCTION}

Sexual violence is often under-reported due to the risks faced by survivors and witnesses who come forward. The risk extends to humanitarian workers, journalists and a number of other people whom survivors of sexual violence approach. Rape and other forms of sexual violence affects the psychological, physical and sexual integrity of the survivors, who are mostly women. Rape is often committed by force, fear or other coercive methods. Sexual violence encompasses an array of abuses, including humiliation, assaults, domestic violence, conflict-related violence, and torture, amongst others. The more a region is exposed to an armed conflict, the greater the prevalence of sexual violence in post-conflict settings in that region.

The author wishes to thank his ex-student and dear friend Mr Dena Mavom de Bior, who is the senior qazette officer and assistant leaal counsel in the Ministry of Justice of the Government of South Sudan. for his assistance in obtainina certain documents. A special word of thanks is also extended to his research assistant Mr Udo Wagener, an LLB student, for his tireless efforts in doing electronic searches for information. 
Impunity for crimes related to sexual violence is largely brought about as a result of legal, institutional, social and cultural factors, as well as a lack of proper investigation and prosecution of crimes of a sexually violent nature. It is in this context that South Sudan has been chosen as a case study. This article therefore questions whether South Sudan has the necessary capacity to successfully criminalize and prosecute crimes related to sexual violence, irrespective of whether the crimes were committed during an armed conflict or not. In this regard the author firstly sketches a brief historical background to the emergence of South Sudan as the newest country in the world.

Secondly, the legal framework of South Sudan is considered. This is done by considering the significance of customary law and how it can create barriers for effective prosecution of crimes relating to sexual violence, as well as the limited protection customary law offers women who have become victims of sexual violence. Statutory and international laws are also considered in order to assess whether South Sudan has the necessary legislative framework to effectively criminalize and prosecute offenders of such crimes.

Thirdly, the role of the United Nations in South Sudan is analyzed. In this regard particular attention is given to the works of the United Nations Mission in South Sudan, together with certain recommendations made by the Mission. Some important Security Council resolutions are also briefly discussed, with particular reference to the extension of the mandate given to the United Nations Mission in South Sudan until November 2014.

Lastly, an interim report from the South Sudan Human Rights Commission is taken into account. A report presented to the Security Council by a nongovernmental organization, called the NGO Working Group on Women, Peace and Security, provides some insight into recent violations of human rights relating to sexual violence in South Sudan. Also, the active role of civil society in South Sudan is briefly looked at. What follows is a brief historical overview of South Sudan.

\section{BRIEF HISTORICAL BACKGROUND OF SOUTH SUDAN $^{1}$}

On 9 July 2011 the Republic of South Sudan became a sovereign state - the youngest state on the African continent to date. The attainment of statehood resulted primarily from two civil wars ${ }^{2}$ fought by the Sudan People's Liberation Army. ${ }^{3}$ These civil wars left South Sudan and its people with poor infrastructure, a myriad of internally displaced people and refugees, with women and children suffering the most. The signing of the Comprehensive Peace Agreement in 2005 between the SPLM and the Government of Sudan marked the end of arguably Africa's longest civil war. This peace agreement paved the way for the people in the south to decide, through a referendum,

\footnotetext{
1 A more detailed historical overview http://www.southsudanembassydc.org/PDFs/Short History.pdf (accessed 2014-05-06).

2 The two civil wars occurred during the periods 1955-1972 and 1983-2005.

3 Hereinafter "the SPLA". The SPLA is the military wing of the Sudan People's Liberation Movement - hereinafter "the SPLM".
} 
whether they want to remain under the authority of the Government of Sudan in the north, or whether they want to secede. An overwhelming majority of southerners opted to secede, leading to the birth of the Republic of South Sudan in July 2011. The values underpinning this new nation include justice, equality and respect for human dignity.

The promulgation of the Transitional Constitution of the Republic of South Sudan $^{4}$ in 2011 formed the basis of governance for the Republic. The following section considers the legal framework and how it applies in South Sudan in the context of protection afforded to women amidst the ongoing armed conflict.

\section{LEGAL FRAMEWORK APPLICABLE IN SOUTH SUDAN}

This section deals with the legal framework applicable within the Republic of South Sudan, in so far as it relates to women in general, and sexual violence in particular. Currently South Sudan is undergoing a constitutional review process, which will eventually result in the adoption of a final constitution. ${ }^{5}$ The National Constitutional Review Commission has the arduous task of drafting the final constitution. ${ }^{6}$ In the meantime, amidst ongoing internal armed conflict, ${ }^{7}$ the supreme law of the land is the Transitional Constitution, ${ }^{8}$ which requires that the Government be structured according to the separation-of-powers principle. ${ }^{9}$ The Transitional Constitution contains a Bill of Rights. ${ }^{10}$ The Bill is justiciable, but the effectiveness of this remains to be

4 Transitional Constitution of the Republic of South Sudan, 2011, hereinafter "the Transitional Constitution" http://www.goss.org/docs/Transitional\%20Constitution\%20of\%20South\%20 Sudan.pdf (accessed 2014-05-06). The Preamble states that "We, the People of South Sudan, ... Do hereby, through this South Sudan Legislative Assembly, amend the Interim Constitution of Southern Sudan, 2005, which shall be adopted and hereafter referred to as the 'Transitional Constitution of the Republic of South Sudan, 2011' and shall be the supreme law by which the independent and sovereign South Sudan shall be governed during the Transitional period, and undertake to abide, respect and defend it."

5 A final constitution has not yet been adopted as at the time of publication of this article.

6 The Commission was established on 9 January 2012. In March 2013 Commission had its mandate extended for a further 2 years. The date for submitting a final draft is set for 9 January 2015. This will seemingly allow the Commission to engage in more intimate awareness campaigns and greater public participation.

7 In July 2013 President Salva Kiir Mayardit made some changes to his cabinet. In the process, the Vice-President, Riek Machar, and a number of ministers, were dismissed. This reshuffling had the effect of aggravating tensions within the SPLM. The majority Dinka tribe in the SPLM is loyal to President Kiir, while the minority Nuer tribe is loyal to the ousted VicePresident Machar. Tribal rivalry between the Dinka and the Nuer erupted on 15 December 2013 in the capital city of Juba, and spread to Jonglei, Unity and the Upper Nile States. This rivalry has escalated to meet the international humanitarian-law threshold of a noninternational armed conflict.

8 See Article 3 of the Transitional Constitution.

9 According to this principle, the Republic of South Sudan is divided into the executive, the legislature and the judiciary. Each branch has separate and independent powers and duties in relation to the other branches.

10 See Part Two of the Transitional Constitution. Article 16 deals with the rights of women. It is interesting to note that the Bill of Rights does not contain a general limitations clause in terms of which rights may be limited, save for specific circumstances spelt out in particular provisions. See, eg, Article 11 (Life and Human Dignity), where it is stipulated that "no-one shall be arbitrarily deprived of his or her life" and Article 12 (Personal Liberty), where it is stipulated that "no person shall be subject to .... restriction of his or her liberty except for specified reasons and in accordance with procedures prescribed by law". 
seen, as there are no reported cases to date that have challenged any of its provisions domestically. The entire legal system, subject to the Transitional Constitution, ${ }^{11}$ is made up of statutory and customary laws.

This section therefore firstly considers the concept of customary law as it is applied in South Sudan; secondly, statutory laws and where applicable, international laws, will be considered. Each of these two aspects will conclude with a brief discussion on the effectiveness of these laws, and ultimately whether victims of sexual violence have adequate protection within the legal framework of the Republic of South Sudan.

\section{Customary laws of South Sudan}

It is generally agreed that there are about fifty different tribes in the Republic of South Sudan, each having its own tribal identity. Day-to-day life in South Sudan has largely been regulated by the customs and practices of the people of South Sudan. One of the reasons why tribal regions lack homogeny is war. Civil wars over the past few decades have resulted in the displacement of thousands of people, accompanied by clashes of culture and customs predominantly as a result of the intermixing of different tribes. ${ }^{12}$ Justice Jok et al provides a definition of customary law applicable in South Sudan as follows

"It is however generally accepted that the term 'customary law' in Southern Sudan refers to the body of custom and tradition that is utilized by, and unites, the majority of citizens in that jurisdiction. It is most important to understand [that] customary law or 'custom' in the South Sudanese context also refers to the practice of Islamic law by South Sudanese Muslims. This is a reflection of the South Sudanese peoples' inclination for the widest interpretation of custom and an expression of their society's preference for religious tolerance."

Article thirty-three of the Transitional Constitution entrenches the rights of ethnic and cultural communities. ${ }^{14}$ It does not expressly create any limitation on how these rights are to be practised, save for the provision that it must occur within "the context of the constitution and the law". In this regard the Local Government Act ${ }^{15}$ describes how decentralization and local

11 See Article 3(3) of the Transitional Constitution.

12 Jok, Leitch, and Vandewint for World Vision International and the South Sudan Secretariat of Legal and Constitutional Affairs "A Study of Customary Law in Contemporary Southern Sudan" March 2004 http://www.cmi.no/sudan/resources.cfm?id=710- (accessed 2014-05-06) 6.

13 Jok, Leitch, and Vandewint for World Vision International and the South Sudan Secretariat of Legal and Constitutional Affairs "A Study of Customary Law in Contemporary Southern Sudan" March 2004 http://www.cmi.no/sudan/resources.cfm?id=710- (accessed 2014-05-06) 11.

14 Article 33 states that "Ethnic and cultural communities shall have the right to freely enjoy and develop their particular cultures. Members of such communities shall have the right to practice their beliefs, use their languages, observe their religions and raise their children within the context of their respective cultures and customs in accordance with this Constitution and the law."

15 Local Government Act, 2009. The enactment of this law was done in accordance with Article $59(2)$ (b) of the Interim Constitution (dealing with the powers and functions of the Legislative Assembly) read with Article 85(1) of the Interim Constitution (dealing with the power of the President to assent to and sign bills into law). 
government operate in South Sudan. The Act also describes the rights of women at community and local-government level. Section 110 stipulates that women shall be accorded full and equal dignity of the person with men, ${ }^{16}$ and require that local-government councils enact laws to combat harmful customs and traditions which undermine the dignity and status of women. ${ }^{17}$ This section mirrors the constitutional right afforded to women in article sixteen of the Transitional Constitution. The Act further describes the recognition of customary courts in South Sudan. For ease of reference, a brief discussion of these courts will be undertaken. ${ }^{18}$

In terms of the Local Government Act, customary-law courts are recognized as courts with limited powers. These courts do not have inherent power to hear matters of a criminal nature, such as sexual violence against a woman for example. In terms of the Act, criminal matters are required to have a "customary interface" and must have been referred to the customary court by a statutory court. ${ }^{19}$ This provision in the Local Government Act is plausible, as the provisions of statutory law are arguably more accessible in statutory courts than unwritten customary-law provisions are in customary courts. Despite this, the majority of civil and criminal cases are often adjudicated before the customary courts, thus blurring the line between the customary courts and statutory courts of first instance. Other substantive laws creating the framework for the operation of customary courts include the Judiciary of Southern Sudan Act of 2008, the Ministry of Legal Affairs and Constitutional Development Act of 2008 and the Codes of civil and Criminal Procedure. The laws available to the chiefs in customary courts consist of traditional practices, statutory provisions that are known to the chief, ${ }^{20}$ and non-statutory forms of mediation between the disputing parties. Apart from these difficulties, more pressing issues relating to the potential conflict between customary law and other systems of law need to be addressed.

Some examples of conflict of laws include those between customary law on the one hand and statutory law and international law on the other. Statutory law in South Sudan is relatively new and the development of courts, judges and other supporting structures are needed. ${ }^{21}$ In terms of Recommendation 5.1.5 of the United Nations Handbook for Legislation on

6 S 110(1) of the Local Government Act, 2009.

7 S 110(4) of the Local Government Act, 2009.

8 The customary courts are generally organized in two levels where lower-level B courts exist in every Payam (a Payam is the second lowest administrative division. It is ranked below a county), and only has jurisdiction up to a maximum penalty. The higher level-C court is set up in each county.

19 S 98(2) of the Local Government Act, 2009.

20 In this regard, customary courts in urban areas are more likely to adopt a more formalistic process of adjudication akin to statutory courts. This could be due to the educational level of the chief in urban areas. It is also interesting to note that traditional practice is passed down orally. Also, the common-law concept of stare decisis is generally not applied.

21 Jok, Leitch, and Vandewint for World Vision International and the South Sudan Secretariat of Legal and Constitutional Affairs "A Study of Customary Law in Contemporary Southern Sudan" March 2004 http://www.cmi.no/sudan/resources.cfm?id=710- (accessed 2014-05-06) 29. 
Violence against Women, ${ }^{22}$ should there be conflict between customary law and the formal justice system, the matter should be resolved with respect for the human rights of the survivor and in accordance with gender-equality standards. It is often the case that the international community criticizes customary laws in light of a human-rights dispensation, paying particular attention to the protection of women and children in some patriarchal societies. $^{23}$

To this end, the European Parliamentarians with Africa, an NGO based in Amsterdam, devised a programme that sought to strengthen the capacity of local councilors through extensive training. Special emphasis was placed on the promotion and respect for human-right rights, peace and reconciliation as well as gender equality. ${ }^{24}$ The project, led by Kristien Debref, was devised for support to the local councils of Western Equatoria and the Eastern Equatoria states of South Sudan.

The role of the United Nations Development Programme also needs mentioning at this juncture. ${ }^{25}$ After signing the Comprehensive Peace Agreement in 2005, efforts to develop legal institutions and promote the rule of law in South Sudan have been guided by the principle that the justice system must be reflective of the values, traditions and identity of the South Sudanese people. On 7 October 2009 the Ministry of Justice adopted a customary-law strategy. This strategy was supported by the United Nations Development Programme and various stakeholders, and has five strategic objectives namely (i) the ascertainment of the customary laws of communities in South Sudan, (ii) the establishment of an institutional focal point to facilitate and co-ordinate customary-law reform, (iii) to engage with communities in order to promote grassroots dialogue and momentum for customary-law reform, (iv) to create a legal framework to harmonize customary and statutory laws, and (v) to conduct further research on customary-law matters. ${ }^{26}$ At the core of these objectives is the establishment of a Customary Law Centre which is intended to facilitate coordination between Government stakeholders of the customary justice system. The Centre will also provide advice and training to branches of government, and serve as the repository for all relevant customary-law research and reference materials.

22 "Handbook for Legislation on Violence against Women", UN Doc ST/ESA/329, 2009 http://www.un.org/womenwatch/daw/vaw/handbook/Handbook\%20for\%20legislation\%200n \%20violence\%20against\%20women.pdf (accessed 2014-06-10) 16.

23 Jok, Leitch, and Vandewint for World Vision International and the South Sudan Secretariat of Legal and Constitutional Affairs "A Study of Customary Law in Contemporary Southern Sudan" March 2004 http://www.cmi.no/sudan/resources.cfm?id=710- (accessed 2014-05-06) 31.

24 A more detailed description of the works of the European Parliamentarians with Africa (AWEPA) project http://www. awepa.org/wp-content/uploads/2013/12/DecentralisationParticipants-manual-final-2.pdf (accessed 2014-05-20).

25 UNDP "Customary Law in South Sudan" 19 September 2012 http://www.ss.undp.org/ content/south_sudan/en/home/library/focus_on_results/dem_gov/customary-law-in-southsudan/ (accessed 2014-06-26). As this work of the UNDP is focusing on customary law, it is included in this discussion as opposed to the general discussion below on the United Nations.

26 A more detailed description of the works of the European Parliamentarians with Africa (AWEPA) project http://www.awepa.org/wp-content/uploads/2013/12/DecentralisationParticipants-manual-final-2.pdf (accessed 2014-05-20). 
Women's security related to domestic violence, adultery and sexual violence in South Sudan is by and large linked to the institution of marriage. For example, according to a South Sudan Human Security Baseline Assessment Report, ${ }^{27}$ customary law makes provision for a certain level of violence in the home and permits a man to "discipline" his wife. Despite statutory laws prohibiting sexual violence, many sexual-violence cases do not reach the courts. Very often women are forced to marry their rapists as it prevents men from going to jail and further avoids the stigma attached to women who have been raped. ${ }^{28}$ Where a perpetrator is successfully prosecuted, the sanction is often a short-term prison sentence. There are significant barriers to justice and redress that deter survivors of sexual violence from seeking assistance. This is often exacerbated by gaps in legislation. Survivors who are unable to assist in the prosecution of an offender, are often charged with adultery. Customary law in South Sudan as it currently stands does not provide sufficient protection for women, especially in the case of sex-related crimes. There is urgent need for legislative reform in this regard. For example, the Local Government Act could remove provisions in it that grant customary courts jurisdiction over women, especially where those women have suffered one or other violation of a fundamental human right and need urgent redress via the criminaljustice system of South Sudan. The application of customary law played a significant role in regulating the daily lives of people during the two civil wars leading up to independence. It is therefore not surprising that a large number of South Sudanese feel very passionate about many of the customary laws. However, in light of its independence and particularly its formal membership to the international community, the role of human rights is going to play an increasingly important role, requiring some level of reform to existing customary rules, especially those affecting women. What follows is a discussion on some pertinent aspects of the statutory laws applicable in South Sudan, as well as a reflection on international human-rights laws.

\section{Statutory law and international law}

In 1984, the Penal and Discipline Law of the SPLA was drafted, and applied to civilians and the military. It remained in force until 2003, except that its applicability to civilians was repealed in 1994. Many of the statutory laws in South Sudan were built on resolutions taken at the occasion of the SPLM Convention of $1994 .{ }^{29}$ The 1984 laws were repealed in 2003 and replaced by the SPLA Act of 2003, which Act in turn was repealed by the SPLA Act of 2009. A number of laws have been passed since 2005. The use of these laws in legal disputes have been limited as a result of poor dissemination of these laws, insufficient experience regarding matters of interpretation, and lack of access to statutory courts.

\footnotetext{
27 Human Security Baseline Assessment for Sudan and South Sudan, "Women's Security and the Law in South Sudan" February 2012 http://www.cmi.no/sudan/resources.cfm?id=882womens-security-and-the-law-in-south-sudan (accessed 2014-06-10). 
The Transitional Constitution makes provision for the National Legislature of South Sudan. ${ }^{30}$ The role of the National Legislature includes, amongst others, the enacting of legislation. Legislation passed prior to 2011 shall be considered, as no relevant legislation post-2011 is evident. The relevant provisions in the Interim Constitution relating to women will briefly be dealt with. This section will also consider applicable international laws relating to the rights of women. The legislation that will be considered includes the Penal Code of 2009, the South Sudan Code of Criminal Procedure Act of 2008, and the Code of Evidence Act of 2009.

The Transitional Constitution is the starting point in establishing what constitutional rights and protections women in South Sudan have. The only notable provisions are contained in article sixteen. Article sixteen also places a positive obligation on the Government to enact laws to combat harmful customs and traditions which undermine the dignity and status of women. The Transitional Constitution does not provide any guidance as to what this obligation entails or how it is to be achieved. Article thirty-three dealing with the rights of ethnic and cultural communities makes it clear that ethnic and cultural communities have the right to freely enjoy and develop their particular cultures. When exercising these rights, members of such communities must do so "in accordance with the constitution and the law". The Interim Constitution does not provide any means of dealing with conflicting provisions in it. Usually courts would engage in interpreting the provisions and come to a meaningful conclusion. To date none of these mentioned provisions has been challenged. Thus courts, including customary courts, could potentially engage in ad hoc interpretation and application of laws, be it statutory or customary, to the detriment of the person wishing to enforce these rights.

The Code of Evidence Act of 2009 is worth mentioning in the context of rape. Section $164,{ }^{31}$ dealing with "evidence to impeach the credibility of a witness" states that when a man is being prosecuted for rape or an attempt to commit rape, it may be shown that the alleged victim was generally of immoral character. ${ }^{32} \mathrm{~A}$ conflict of legal provisions once again appears, as most of the cases dealing with women are brought before the customary courts. ${ }^{33}$ Should a conviction not be secured for the reason that "the victim is of immoral character", that victim may be charged with adultery and face imprisonment.

The Penal Code Act of 2008 provides for certain protection for women and children as vulnerable groups, but this protection is simply not enough when it comes to sexual violence against women. Rape, for example, is specifically defined of the Act. Two concerns can be noted. Firstly, the Act provides that sexual intercourse by a married couple is not rape, "within the meaning of this section". ${ }^{34}$ Courts could easily interpret this section to mean

Article 54 of the Transitional Constitution.

S 164 of the Code of Evidence Act, 2009

32 Ibid; and s 164(1)(d) of 2009.

33 Hence the need to exclude women issues (where sex-related offences are concerned) from the jurisdiction of the customary courts, by amending the Penal Code Act.

${ }^{34} \mathrm{~S} 147(3)$ of the Penal Code Act, 2008. 
that, where a married complainant claims that her husband forced her to have sexual intercourse against her will, such sexual intercourse will not constitute rape. At best it could fall under some other lessor crime. A better interpretation would be to regard the words "within the meaning of this section" as referring to subsection one of section 147, where express mention is made of "against his or her will, or without his or her consent". Thus, in terms of this proposed interpretation, a married woman who does not give consent to sexual intercourse ought to have the right to claim that she was raped. This would clearly be in line with the rights afforded to women in terms of the Transitional Constitution. ${ }^{35}$

The second concern relates to invoking the right of private defence. Where a person is accused of killing another person in private defence the reasons for such killing could include the fact that the person acting in private defence was raped, or suffered grievous hurt. ${ }^{36}$ There is, however, a limitation placed on this right when private defence is done against a public servant, such as a member of the SPLA. The provision stipulates that there is no right of private defence against an act which does not cause apprehension of death or grievous hurt, if done or attempted to be done by a public servant acting in good faith under the colour of his or her office, or at the instructions from his superior, despite those instructions not being "justifiable by law". ${ }^{37}$ Rape and other sex-related offences are excluded, and do not fall under the narrowly-defined definition of "grievous hurt". ${ }^{38}$ In terms of this provision a public servant can therefore rape a woman (under the guise that "it was a directive given"), with the result that the woman will not be able to claim private defence under the Act if she opts to defend herself against rape by that public servant.

The Act deals with other forms of sexual offences under chapter eighteen. Such offences include unnatural offences, gross indecency, public indecency and prostitution. The Act does not deal with sexual slavery, given that sexual slavery against women has reportedly been committed since December 2013.

There are many gaps in national legislation which undermine the protection of international human rights. With regard to international humanrights law, South Sudan has not formally ratified key international humanrights treaties, except for the 1989 Convention on the Rights of the Child, the 1984 Convention against Torture, and the 1990 African Charter on the Rights and Welfare of the Child. ${ }^{40}$ The International Committee of the Red

35 Article 16(1) and 4(b) of the Transitional Constitution. This might be challenged under customary-marriage law.

${ }^{36} \mathrm{~S} 45$ of the Penal Code Act, 2008

37 S 44 of the Penal Code Act, 2008

38 S 235 of the Penal Code Act, 2008 defines the term "grievous hurt" in a narrow sense.

39 UNMISS "Conflict in South Sudan - A human Rights Report" 8 May 2014 http://www.un miss.unmissions.org/Portals/unmiss/Human\%20Rights\%20Reports/UNMISS\%20Conflict\%2 0in\%20South\%20Sudan\%20-\%20A\%20Human\%20Rights\%20Report.pdf (accessed 201406-06).

40 Examples of international treaties not yet ratified include the International Covenant on Civil and Political Rights, 1966; the Convention on the Elimination of all forms of Discrimination against Women, 1979; the African Charter on Human and Peoples' Rights, 1981 (South Sudan has signed this instrument); the International Covenant on Economic, Social and Cultural Rights, 1966; and the International Convention on the Elimination of All Forms of 
Cross has expressed satisfaction after learning that South Sudan has acceded to the four Geneva Conventions of 1949 and their Additional Protocols in July $2012 .{ }^{41}$ As the newest state joining the international community, South Sudan has major work to be done in the area of the promotion and respect for human rights. By ratifying and domesticating international human-rights instruments, South Sudan is one step closer to fulfilling its obligations towards its citizens - the next step would be to disseminate the information to everyone, and this can prove to be a major challenge. Lack of technology, poor infrastructure and lack of fully-trained personnel makes this task even more difficult. A brief discussion of the role of the United Nations and its impact in South Sudan in so far as it creates some form of assistance for the protection of women against sexual violence, particularly in the context of an armed conflict, will now be undertaken.

\section{4 \\ THE ROLE OF THE UNITED NATIONS IN SOUTH SUDAN}

The United Nations Security Council ${ }^{42}$ acting under Chapter Seven of the Unite Nations Charter and by its resolution $1996^{43}$ of 8 July 2011, established the United Mission in the Republic of South Sudan. ${ }^{44}$ UNMISS was mandated to be active in the region for a period of one year from 9 July 2011 with the possibility of renewing the mandate, depending on the circumstances. Resolution 1996 recalls the need to address violence against women and girls as a tool of warfare. Moreover, the resolution required UNMISS to (i) support the Government in peace consolidation and thereby fostering longer-term state building and economic development; (ii) assist the Government in exercising its responsibilities for conflict prevention, mitigation and resolution and protect civilians; and (iii) help the authorities in developing capacity to provide security, establishing the rule of law and strengthening the security and justice sectors in the country. The initial mandate was extended three times since its inception, and will end on 30 November $2014 .{ }^{45}$

On various occasions the Security Council has called upon all parties to promote and protect human rights, including those of women and people belonging to vulnerable groups, to comply with their obligations under international law, including international humanitarian and international

Discrimination, 1965. South Sudan has ratified seven of the International Labour Organization's Conventions.

41 ICRC "South Sudan: world's newest nation signs up to the Geneva Conventions" 19 July $2012 \mathrm{http}: / /$ www.icrc.org/eng/resources/documents/news-release/2012/so uth-sudan-news2012-07-09. htm (accessed 2014-06-25). The ICRC has a delegation in Juba and three subdelegations in Malakal, Bentiu and Wau. Its operations in Southern Sudan began in 1986.

42 Hereinafter "the Security Council".

43 SC Res. 1996 of 8 July 2011.

44 Hereinafter "UNMISS".

45 UNMISS's mandate was extended to 15 July 2013 by SC Res. 2057 of 5 July 2012. A further extension to 15 July 2014 was made by SC Res. 2109 of 11 July 2013. The latest extension to 30 November 2014 was made by SC Res. 2155 of 27 May 2014. 
human-rights law, and calls for those responsible for serious violations of such law, including sexual violence, to be held accountable. ${ }^{46}$

On 15 December 2013, violence broke out in the capital city of Juba between the ruling party's Dinka tribe and the smaller Nuer tribe under the leadership of Riek Machar, the ousted vice-president of South Sudan. As a result, resolution $2132^{47}$ was adopted in order to increase the overall troop and police strength of UNMISS. The Security Council on 27 May 2014 unanimously adopted resolution $2155^{48}$ wherein it authorized UNMISS to use all necessary means to protect civilians, monitor and investigate human rights, to create conditions for the delivery of humanitarian assistance and to support the implementation of the cessation of hostilities agreement. To this end, the protection of civilians includes protection under the threat of physical violence, irrespective of the source of the violence. It also includes specific protection of women and children. In so far as its monitoring and investigative mandate is concerned, UNMISS is required to verify and report specifically and publically on violations of human rights and violations and abuses committed against children and women, including all forms of sexual and gender-based violence in armed conflict by accelerating the implementation of monitoring, analysis and reporting arrangements on conflictrelated sexual violence and by strengthening the monitoring and reporting on mechanisms for preventing grave violations against children.

On 21 February 2014 UNMISS presented the United Nations with an interim report relating to the human rights situation in South Sudan. ${ }^{49}$ The report emphasizes the difficulties in gaining accurate information and statistics due to lack of reporting of incidents. The report suggests that sexual violence forms a consistent characteristic of the crisis in all of the affected states. ${ }^{50}$ The investigations done by the Human Rights Division of UNMISS suggest that the alleged perpetrators include members of the SPLA, the SSNPS, and opposition forces who committed sexual violence, including rape, forced abortion and sexual harassment. ${ }^{51}$ It is reported that civilians of the Dinka and Nuer tribes were specifically targeted during the perpetration of such sexual offences. The final, more comprehensive report for the said period was made available on 8 May $2014 .^{52}$ In addition to the

46 SC Res. 2046 of 2 May 2012; SC Res. 2132 of 24 December 2013 (condemning general violence in the region); SC Res. 2109 of 11 July 2013 (particularly stressing the need for access to justice); and SC Res 2155 of 27 May 2014 (particularly condemning rape, sexual and gender-based violence).

47 Ibid.

48 Ibid.

49 Interim Report on Human Rights - Crisis in South Sudan, UNMISS, 21 February 2014. The report covers the period 15 December 2013 to 31 January 2014. The Human Rights Division (HRD) of UNMISS has the mandate to investigate and report on violations of international humanitarian and human-rights law.

50 Interim Report on Human Rights - Crisis in South Sudan, UNMISS, 21 February 2014. The report covers the period 15 December 2013 to 31 January 2014. The Human Rights Division (HRD) of UNMISS has the mandate to investigate and report on violations of international humanitarian and human-rights law 9. UNMISS cannot verify whether sexual violence was used as a weapon of war, since many of the incidents were still being investigated at the time of drafting the interim report.

51 Ibid.

52 UNMISS "Conflict in South Sudan - A human Rights Report" 8 May 2014 http://www.un miss.unmissions.org/Portals/unmiss/Human\%20Rights\%20Reports/UNMISS\%20Conflict\%2 
interim report, this more recent report confirms that the alleged perpetration of sexual violence by security forces undermines the credibility of these institutions to receive reports of sexual violence. Other factors which prevent victims from reporting to security, social welfare and judicial actors include closure of Government offices and social stigma. ${ }^{53}$ It is reported that the incidence of sexual violence since 15 December 2013 increased in at least 4 states, namely Central Equatoria State, ${ }^{54}$ Jonglei State, ${ }^{55}$ Upper Nile State, ${ }^{56}$ and Unity State. ${ }^{57}$

On 13 March 2014 the Secretary-General of the United Nations presented a report to the Security Council on conflict-related sexual violence. ${ }^{58}$ The report covers the period from January to December 2013. The report makes specific reference to the UNMISS interim report discussed above, and makes it clear that the term "conflict-related sexual violence" relates to rape, sexual slavery, forced prostitution, forced pregnancy, forced sterilization and any other forms of sexual violence of comparable gravity perpetrated against women, men or children with a direct or indirect (temporal, geographical or causal) link to a conflict. ${ }^{59}$ The Secretary-General noted in his report the abduction of 32 women who were reportedly forced to walk naked from their village to a military barracks and were "assigned" to SPLA soldiers and militia members. The return of these women was facilitated by governmental, civil society and United Nations actors. ${ }^{60}$ The report further notes that during

0in\%20South\%20Sudan\%20-\%20A\%20Human\%20Rights\%20Report.pdf (accessed 201406-06).

53 UNMISS "Conflict in South Sudan - A human Rights Report" 8 May 2014 http://www.un miss.unmissions.org/Portals/unmiss/Human\%20Rights\%20Reports/UNMISS\%20Conflict\%2 0in\%20South\%20Sudan\%20-\%20A\%20Human\%20Rights\%20Report.pdf (accessed 201406-06) par 252.

54 UNMISS "Conflict in South Sudan - A human Rights Report" 8 May 2014 http://www.un miss.unmissions.org/Portals/unmiss/Human\%20Rights\%20Reports/UNMISS\%20Conflict\%2 0in\%20South\%20Sudan\%20-\%20A\%20Human\%20Rights\%20Report.pdf (accessed 201406-06) par 254. At least twenty-two incidents were attributed to the SPLA, including fourteen incidents of rape and gang-rape.

55 UNMISS "Conflict in South Sudan - A human Rights Report" 8 May 2014 http://www.un miss.unmissions.org/Portals/unmiss/Human\%20Rights\%20Reports/UNMISS\%20Conflict\%2 0in\%20South\%20Sudan\%20-\%20A\%20Human\%20Rights\%20Report.pdf (accessed 201406-06) par 255. Five incidents of rape and four incidents of gang rape were reported. The SPLA were reportedly involved in six of these acts, while the opposition forces were involved in three.

56 UNMISS "Conflict in South Sudan - A human Rights Report" 8 May 2014 http://www.un miss.unmissions.org/Portals/unmiss/Human\%20Rights\%20Reports/UNMISS\%20Conflict\%2 0in\%20South\%20Sudan\%20-\%20A\%20Human\%20Rights\%20Report.pdf (accessed 201406-06) par 257. Two incidents of opposition soldiers capturing women and holding them for many days in a house (as "wives") where they were raped.

57 UNMISS "Conflict in South Sudan - A human Rights Report" 8 May 2014 http://www.un miss.unmissions.org/Portals/unmiss/Human\%20Rights\%20Reports/UNMISS\%20Conflict\%2 0in\%20South\%20Sudan\%20-\%20A\%20Human\%20Rights\%20Report.pdf (accessed 201406-06) par 258. Twenty-five incidents of conflict-related incidents were reported. Victims included foreign nationals, and persons from the Nuer and Equatorian ethnicity.

58 Report of the Secretary-General, UN Doc. S/2014/181, 13 March 2014.

59 Report of the Secretary-General, UN Doc. S/2014/181, 13 March 2014 par 1.

60 Report of the Secretary-General, UN Doc. S/2014/181, 13 March 2014 par 47 . Prior to 15 December 2013, the SPLA had made efforts with respect to accountability, by reporting that eight verdicts against SPLA soldiers and officers for rape had been secured. UNMISS also conducted 42 training sessions to raise awareness about conflict-related sexual violence, including for SPLA and the SSNPS. UNMISS women protection advisors led a legislative review task-force that recommended that the definition of rape in the Penal Code Act, 2008 
2013 legislation was passed to ratify the Convention on the Rights of the Child and the Convention against Torture, Inhuman or Degrading Treatment or Punishment. In relation to the crisis that emerged on 15 December 2013, The Secretary-General made certain recommendations ${ }^{61}$ by firstly urging the parties to abide by the commitments that they made in the "Cessation of Hostilities Agreement" of 23 January $2013^{62}$ in Addis Ababa, Ethiopia. In particular, one of the recommendations is that the parties refrain from attacking civilians, including by committing acts of rape or sexual abuse, and to ensure accountability for sexual-violence crimes. It is also recommended that the Government of South Sudan pursue legislative reform and capacitybuilding efforts of the security and justice sectors necessary to comprehensively address sexual violence. ${ }^{63}$

The United Nations continues to play an integral, supportive role in its attempts to ensure that crimes relating to sexual violence in South Sudan are eradicated. This is further evidenced by the presence of the United Nations Police in South Sudan. ${ }^{64}$ Non-governmental organizations, civil society and a national human-rights commission can play a huge role in identifying, monitoring and reporting violations of human rights in the country. What follows is a discussion on these organizations relevant to South Sudan.

\section{THE SOUTH SUDAN HUMAN RIGHTS COMMISSION AND OTHER ORGANIZATIONS' REPORTS ON SEXUAL VIOLENCE IN SOUTH SUDAN}

During an armed conflict violations of human rights often go undetected and unreported. Reliance is then placed on the business of organizations championing the advancement, respect and protection of human rights. This section will look at the interim report of the South Sudan Human Rights Commission, reports from the NGO Working Group on Women, Peace and Security, and the South Sudan Civil Society.

\section{South Sudan Human Rights Commission ${ }^{65}$}

The Commission receives it mandate from the Transitional Constitution. ${ }^{66}$ The interim report ${ }^{67}$ of the Commission reflects the human rights situation in

be revised and also that amendments be made to the Local Government Act to remove provisions that grant the customary justice-system jurisdiction over women.

61 Report of the Secretary-General, UN Doc. S/2014/181, 13 March 2014 par 49.

62 IGAD "Agreement on Cessation of Hostilities between the Government of the Republic of South Sudan (GRSS) and the Sudan People's Liberation Movement/Army (in opposition) (SPLM/A in opposition)" 23 January 2013 http://enoughproject.org/files/IGAD_Cessa tionofHostilitesGRSS.pdf (accessed 2014-06-03).

63 Report of the Secretary-General, UN Doc. S/2014/181, 13 March 2014 par 49.

64 The aims of the UN Police are to (i) strengthen capacity of the SSNPS, (ii) advise and assist SSNPS at national and local levels in fulfilling their responsibility to protect civilians, and (iii) support the South Sudanese Government in co-operation with international partners in developing strategies for the security-sector reform and the rule of law, and to build capacity in the area of human rights http://unmiss.unmissions.org/Default.aspx?tabid=5406\& language=en-US (accessed 2014-06-03).

65 Hereinafter "the Commission". 
South Sudan during the period 15 December 2013 to 15 March 2014. Owing to the prevailing internal armed conflict and the resultant insecurity in South Sudan, the collection of information for the report proved to be challenging, resulting in the Commission using three innovative methods to determine the nature and level of human-rights violations associated with the crisis. ${ }^{68}$ The Commission observed that since December 2013 there had been major setbacks in the areas of human-rights protection and respect for fundamental rights. ${ }^{69}$ Restrictions on the media and freedom of speech have been imposed. Talk-show programmes on Miraya FM, a local radio station, dealing with human rights, governance and the rule of law as well as other social issues were suspended. The relationship between other local media houses and Government has also deteriorated as a result of Government accusing the media houses of incitement and promoting the image of the rebels in their broadcasts. The interim report highlights an array of humanrights violations related to the right to life, destruction of property, ethnicity and tribalism, political detainees and judicial proceedings. Very little is reported about the large-scale incidents of sexual violence against women.

On a more positive note the interim report makes certain recommendations. Some of the recommendations, amongst others, are that the Government of South Sudan should (i) in particular put in place measures to strengthen protection measures for civilians in the states under declared state of emergency, ${ }^{70}$ (ii) support the investigation committee formed by the president of South Sudan in order to expedite the investigation process so as to produce reports that would enable the Government to try and prosecute perpetrators of human-rights violations against civilians, (iii) refrain its forces from violating human rights. The rebel groups are required to respect and protect human rights and to allow members of civil-society organizations to carry messages of peace to their areas of control and protect and consider them as messengers of peace, harmony, co-existence and promoters of human rights. It further requires UN agencies and the international community to urge Government and the rebels to cease hostilities in favour of dialogue to reach a political settlement to the conflict as well at putting together a developmental agenda, or

${ }^{66}$ Article 145 of the Transitional Constitution establishes the Commission, and Article 146 describes the functions of the Commission, which includes the mandate to investigate and report on violations of human rights and fundamental freedoms, and to publish periodical reports on its findings and submit annual reports to National Legislative Assembly on the state of human rights and fundamental freedoms.

67 South Sudan Human Rights Commission "Interim Report on South Sudan Internal Conflict" 20 March 2014 http://www.gurtong.net/LinkClick.aspx?fileticket=RO6rWq-_ogw\%3D\&tabid $=124$ (accessed 2014-06-06).

68 The three methods used were (i) covert observation mainly carried out in Juba, (ii) key informant interviews that helped elicit information and directing the monitors to specific human-rights situations and events, and (iii) consulting with other human-rights defenders and monitors across the country.

69 South Sudan Human Rights Commission "Interim Report on South Sudan Internal Conflict" 20 March 2014 http://www.gurtong.net/LinkClick.aspx?fileticket=RO6rWq-_ogw\%3D\&tabid $=124$ (accessed 2014-06-06) 9. Notable atrocities include extra-judicial killing, arbitrary arrests in some areas, rape associated with persons in uniform being on the increase, and a widespread culture of impunity surfacing.

70 At the time of submission of this article three states were under a declared state of emergency namely Jonglei State, Unity State and Upper Nile State. 
humanitarian aid as priority over other interests that they may have. ${ }^{71}$ The Commission has an import role to play in monitoring and reporting humanrights violations in terms of its constitutional mandate.

\section{NGO Working Group on Women, Peace and Security ${ }^{72}$}

The NGO Working Group, formed in 2000, advocates for the full and equal participation of women in all efforts to create and maintain international peace and security. It serves as a bridge between women's human-rights defenders working in conflict-affected situations and policy-makers at the United Nations.

The Working Group believes that a broad and positive impact on the lives of all people experiencing conflict will result from the full implementation on Security Council Resolution $325^{74}$ and the promotion of the Beijing Platform for Action, ${ }^{75}$ CEDAW $^{76}$ and other supporting instruments. On 25 April 2014 Rhoda Misaka addressed the United Nations Security Council Open Debate on Sexual Violence in Conflict. ${ }^{77}$ The focus of her address was on the security situation in South Sudan where she said

"I speak here today with a heavy heart, as I continue to receive reports from my family, friends and my organization in South Sudan that the violence in our country has continued to increase. Women in the UNMISS IDP camp in Bor, which was attacked last week, are traumatized and devastated, and say they feel like they are sitting there waiting to die. I am here with you in the Security Council today, but I live in fear of what will happen next in my country, and to my family. Last week in Bentiu, hundreds of men, women and children were killed, and men being pushed to rape women of different ethnicity."

In her address, Misaka focused on six areas of concern in relation to South Sudan and sexual violence in all conflicts including those situations that do not form part of the focus of the international community. On the

71 South Sudan Human Rights Commission "Interim Report on South Sudan Internal Conflict" 20 March 2014 http://www.gurtong.net/LinkClick.aspx?fileticket=RO6rWq-_ogw\%3D\&tabid $=124$ (accessed 2014-06-06) 11-13.

72 This NGO comprises of a host of organizations including Amnesty international, Human Rights Watch, Global Justice Center, Refugees International and the women's Refugee Commission. For a full list of organizations see http://www.womenpeacesecurity.org (accessed 2014-06-07).

73 lbid.

74 SC Res. 1325 of 31 October 2000. This resolution reaffirms the role of women in the prevention and resolution of conflicts, peace negotiations, peace-building, peace-keeping, humanitarian response and in post-conflict reconstructions and stresses the importance of their equal participation and full involvement in all efforts for the maintenance and promotion of peace and security. It calls on all parties to the conflict to take special measures to protect women and girls from gender-based violence, particularly rape and other forms of sexual abuse in situations of armed conflict.

75 The Beijing Declaration and Platform for Action. The fourth world conference on women was held in Beijing in September 1995 http://www.un.org/womenwatch/daw/beijing/platform/ (accessed 2014-06-07).

76 Convention on the Elimination of all forms of Discrimination against Women "GA Res. 34/180" 1979 http://www.un.org/womenwatch/daw/cedaw/ (accessed 2014-06-07).

77 The full statement http://womenpeacesecurity.org/media/pdf-NGOWGStatement_Open Debate_April2014.pdf (accessed 2014-06-10)

78 lbid. 
point of impunity, Misaka pointed out that the Security Council, the Member States and the United Nations should play an active role in ending impunity, and promoting investigation, documentation and accountability. Regarding services for survivors of sexual violence she called upon Member States and United Nations agencies to ensure that survivors are able to access, in a timely fashion, non-discriminatory and comprehensive health services. She points out that in South Sudan, survivors face a number of barriers to these types of services, including the fact that survivors do not report abuses early enough due to fear and stigma, as well as poor infrastructure and lack of health and psychological services. Amnesty for sexual violence, according to Misaka, should not form part of any ceasefire or peace agreements, as these amnesties make accountability for sexual violence crimes impossible. The remaining areas of concern addressed relates to women's participation in peace negotiations, the UNMISS mandate and root causes to the conflict situation in South Sudan.

Misaka's address to the Security Council is welcomed, as it highlights firsthand the plight of women caught up in conflict situations, as well as the painful difficulties South Sudanese survivors of sexual abuse have. The address also emphasizes the important role of the NGO working Group on Women, Peace and Security in relation to creating awareness at high-level bodies such as the United Nations Security Council.

\section{South Sudan Civil Society}

South Sudan has a vibrant civil society which includes faith-based institutions, people with disabilities, academics, youth and women. A strong and critical civil society contributes to the democratization process and good governance. According to Steven Puoch, president of the National Youth Union, "civil society represents the voice of the voiceless, and any negotiated peace deal must embody and safeguard the values of justice, rule of law, federal governance, accountability and transparency". ${ }^{79}$

The South Sudan Civil Society held a conference in Addis Ababa during March $2014^{80}$ where the Declaration on Civil Society Engagement in the IGAD-Led Peace Process for Sustainable Peace and Development was adopted. Most notably from this declaration, a few aspects are worth noting. Firstly, a call is made for the immediate amendment to the Transitional Constitution of South Sudan, especially in relation to the excessive powers of the executive, the procedure and competence of the National Constitutional Review Commission and the judiciary, in order to ensure respect for the separation of powers. Secondly, restructuring the armed forces and other security organs in order to reflect the diversity of South Sudan. Thirdly, that the role of civil society in matters of reconciliation, justice and peace be enhanced, and to this end for civil society to collaborate with local and international institutions tasked with the

79 Tesfa-alemTekle for Sudan Tribune "S. Sudan civil societies push for inclusion in peace talks" 16 March 2014 http://www.sudantribune.com/spip.php?article50316 (accessed 201406-07).

80 The theme of the conference, with fifty-one participants, was "Sustainable Peace is a Collective Effort". 
investigation and prosecution for extreme cases of human-rights violations. ${ }^{81}$ Lastly, it urges the Inter-governmental Authority on Development to accredit civil-society representatives to the peace process and thus providing a platform for dialogue between civil society and the conflicting parties. Civil society in South Sudan can have persuasive value in the activities that it undertakes in order to remind the Government of its obligations in terms of the Transitional Constitution, as well as its obligations in terms of its relationship to the international community, and more particularly, its obligations to respect, protect and promote the human rights of all its people, especially women subjected to various forms of sexual abuse.

\section{CONCLUSION}

South Sudan is a country rich in culture, tradition, natural resources and people. Women form an integral part of this heritage. They have the same history of bitterness, oppression and suffering as their male counterparts. Yet current domestic laws do not provide sufficient protection for women who have become victims of sexual violence, whether in an armed-conflict situation or not.

The ongoing "impunity syndrome" on the African continent provides little comfort to those women. There has been widespread criticism that the African Union is not doing enough to address the issue of impunity. On 30 December 2013 the African Union Peace and Security Council established the Commission of African Inquiry in order to investigate human-rights violations and other abuses committed during armed conflict in South Sudan. The Commission undertook its first mission to South Sudan in April 2014 and is expected to give its report within a period of three months to the African Union Peace and Security Council. This is a major step in the fight against impunity in African countries, particularly the aversion that some countries display in relation to the jurisdiction of the International Criminal Court.

In terms of Resolution $1325^{82}$ South Sudan embarked on developing a National Action Plan on women, but faces a number of challenges including the lack of gender-based violence laws at national and state levels, and an ongoing preference to deal with gender-based violence matters in customary courts.

The perceptions, understandings and interpretations of customary law and its judicial application must necessarily change. However, this change has to be gradual as customs, beliefs and practices of people cannot be eradicated overnight. It is inevitable that change is necessary, but bringing this about must be done in manner cognizant of a South Sudanese society that is fragile and slowly emerging from decades of war.

81 South Sudan Civil Society "Declaration on Civil Society Engagement in the IGAD-Led Peace Process for Sustainable Peace and Development" 17 March 2014 http://www.gur tong.net/LinkClick.aspx?fileticket=NXfyvMx4g8U\%3d\&tabid=124 (accessed 2014-06-07).

82 See fn 74 above. The resolution recognizes the particular vulnerability of women to sexual violence during times of conflict and in post conflict situations where the rule of law is not yet fully established. 
Domestic laws need to be radically revised so as to increase the prosecution of offenders who commit crimes akin to sexual violence. There is a desperate need to amend the Penal Code Act of 2008 to remove the jurisdiction of the customary courts in so far as it relates to women whose human rights have been violated in the form of sexual violence. At the moment prosecution in statutory courts of such crimes are at a minimum, while transgressions of such crimes are at a maximum, especially in the context of the ongoing internal armed conflict. This being said, one will have to be cautious not to fully and unjustifiably remove the choice that litigants have to bring matters to the customary courts. Some matters must be dealt with in a concurrent jurisdictional fashion (where the statutory courts and the customary courts have equal jurisdiction), while other matters, such as women litigants subjected to sexual violence, must be dealt with in an exclusive jurisdictional sense (where only the statutory courts, or only the customary courts will have jurisdiction).

The presence of UNMISS is South Sudan does to some extent help with general security issues in the region. However, more work needs to be done towards the protection of civilians, human-rights monitoring, support for the delivery of humanitarian assistance and for the implementation of the Cessation of Hostilities Agreement concluded on 23 January 2014. The continued presence of UNMISS until 30 November 2014 is welcomed. In this regard, UNMISS is required to continue to monitor, investigate and verify all forms of violence against women, including sexual and gender-based violence in armed conflict.

Civil society in South Sudan should continue to pressurize Government. Moreover, international organizations and the international community at large should, where possible, provide funding for some of the activities hosted by civil society. The vast majority of members of civil society in South Sudan do not have the necessary funds to contribute to meaningful engagement activities.

John Garang once said, "we have now delivered a healthy robust baby, but this baby needs proper nurturing to grow". ${ }^{83}$ Women in South Sudan are in a unique position to play an integral role in the growth, reconstruction and development of the new South Sudan in all facets, including sensitive issues relating to sexual violence against women.

83 Extract of a speech made by $\mathrm{Dr}$ John Garang De Mabior on the occasion of signing the Nairobi Declaration on launching the final phase of peace in the Sudan, 5 June 2005. John Garang is the revered late leader of the SPLM, and the founding father of South Sudan. 